Available online http://iurnal.unimed.ac.id/2012/index.php/anthropos

\title{
Eksistensi Parmalim Mempertahankan Adat dan Budaya Batak Toba di Era Modern
}

\section{The existence of Parmalim Defends Toba Batak Customs and Culture in the Modern Era}

\author{
Dapot Siregar $^{1)^{*}}$ \& Yurulina Gulo2) \\ 1) Magister Sosiologi Agama, Fakultas Teologi, Universitas Kristen Satya Wacana \\ 2) Alumni Magister Sosiologi Agama, Fakultas Teologi Universitas Kristen Satya Wacana \\ Diterima:20 Januari 2020; Disetujui:04 Maret 2020; Dipublikasi:01 Juni 2020;
}

\section{Abstrak}

Tulisan ini bertujuan untuk mendeskripsikan dan menganalisa secara kritis eksistensi parmalim dalam upaya mempertahankan adat dan budaya Batak Toba di era modern. Masalah difokuskan pada ritus ibadah dan kehidupan sosial parmalim yang ada di Laguboti dan Hutatinggi. Sejauh mana agama Malim menggunakan adat dan budaya Batak Toba dalam setiap ritus dan kehidupan sosial setiap harinya sebagai upaya dalam mempertahankan adat dan budaya Batak Toba di era modern sekarang ini. Guna mendekat masalah ini, peneliti berangkat dari acuan teori modernitas, di mana dalam modernitas menekankan rasional, yang tidak rasional akan ditinggalkan. Selain itu, peneliti juga akan melakukan pendekatan melalui teori fungsi agama, di mana dalam teori fungsi agama bahwa agama masih berfungsi jika mampu memberikan eksplanasi, kenyamanan spritual dan mengikat kohesi sosial yang ada. Metode penelitian yang dilakukan oleh penulis melalui wawancara mendalam dengan beberapa tokoh masyarakat yang meliputi daerah Laguboti dan Hutatinggi dan juga studi kepustakaan.

Kata kunci: Parmalim, Agama Malim, Adat, Budaya, Eksistensi

Abstract

This paper aims to describe and critically analyze the existence of Parmalim in an effort to maintain Toba Batak customs and culture in the modern era. The problem is focused on the rites of worship and social life of Parmalim in Laguboti and Hutatinggi. The extent to which the Malim religion uses the customs and culture of the Toba Batak in every rite and social life every day as an effort to maintain the customs and culture of the Toba Batak in the modern era. To approach this problem, researchers depart from the reference to the theory of modernity, where in modernity emphasizes rational, which is irrational will be abandoned. In addition, researchers will also approach through the theory of the function of religion, in which in the theory of the function of religion that religion still functions if it is able to provide explanation, spiritual comfort and to bind existing social cohesion. The research method was conducted by the writer through in-depth interviews with several community leaders covering the regions of Laguboti and Hutatinggi and also literature studies.

Keywords: Parmalim, Malim Religion, Custom, Culture, Existence

how to Cite: Siregar, D. \& Gulo, Y. (2020). Eksistensi Parmalim Mempertahankan Adat dan Budaya Batak Toba di Era Modern. Anthropos: Jurnal Antropologi Sosial dan Budaya (Journal of Social and Cultural Anthropology) 6 (1): 41-51.

*Corresponding author:

E-mail:dapotswandysiregar@gmail.com,
ISSN 2460-4585 (Print)

ISSN 2460-4593 (Online) 


\section{PENDAHULUAN}

Dalam konteks zaman yang disebut dengan era 4.0 ini yang mengedepankan tekhnologi dan pengetahuan, di mana budaya populer menjadi sesuatu yang sangat diminati ternyata masih ada kelompok masyarakat yang mempertahankan adat budayanya yaitu parmalim. Kelompok masyarakat tersebut menjadikan adat atau budaya sebagai dasar untuk membentuk sebuah kepercayaan. Adat dan kebudayaan itu mengacu kepada perkembangan intelektual seseorang, spritualnya dan juga estetis dari seorang individu, sebuah kelompok ataupun masyarakat (Sutrisno, 2005). Dalam konteks moernitas dan globalisasi, masih terdapat agama yang masih hidup dalam adat dan budaya tradisional bahkan menjadikan agama dan budaya itu menjadi bagian dari kepercayaan dan keyakinannya. Salah satu agama yang masih hidup dalam tatanan adat dan kebuadayaan adalah Agama Malim yang sering juga disebut sebagai parmalim.

Agama Malim merupakan sebuah kepercayaan terhadap Debata Mulajadi $\mathrm{Na}$ Bolon dan ajaran ini sudah ada sejak dahulu kala. Bagi penganut Agama Malim meyakini dan memahami bahwa Debata Mulajadi Na Bolon adalah pencipta segala sesuatu, mulai dari manusia, hewan, tumbuhan, air, tanah, dan lain sebagainya. Pada awalnya agama malim adalah sebuah gerakan masyarakat Batak untuk mempertahankan ajaran adat atau budaya karena ada agama baru yang dibawa oleh Belanda melalui imperialisme dan kolonialisme (Hirosue, 2015). Ciri kehidupan kelompok masyarakat parmalim ini ditandai dengan penekanan yang begitu kuat terhadap adat dan budaya. Cara berpakaian dan aturan kehidupan bersumber dari hukum adat yang diyakini diturunkan oleh Mulajadi na Bolon. Nilainilai modernitas dan globalitas tidak meruntuhkan pola hidup mereka yang menekankan kepada pola hidup yang tradisional.
Istilah Parmalim terdiri dari kata Par dan Malim, dalam bahasa Batak Toba kata Par merupakan awalan aktif yang berarti orang yang mengerjakan atau menganut sesuatu. Kata Malim merupakan kata pinjaman dari masyarakat Islam pesisir pantai. Dalam pemahaman masyarakat pesisir pantai, malim adalah seorang pemuka agama Islam. Dalam bahasa Batak Toba, kata itu merupakan kata sifat yang berarti orang suci, sadar beragama. Penganut agama Malim menjalani kehidupan sebagai "Na Malim" atau yang suci (Siagian, 2016). Pengikut agama Malim menyebut atau mengidentifikasi dirinya sebagai "Parsolam". Pusat Agama malim adalah di Hutatinggi Laguboti (Situmorang, 2009).

Desa Hutatinggi merupakan salah satu desa yang terdapat di Kabupaten Toba Samosir, tepatnya di Kecamatan Laguboti, yang juga merupakan bagian dari Desa Pardomuan Nauli, tetapi masyarakat lebih mengenal desa ini sebagai Desa Hutatinggi. Desa Hutatinggi diketahui sebagai tempat bermukimnya para penganut kepercayaan lokal yang masih ada di tanah Batak yang disebut dengan Parmalim yang saat ini dipimpin oleh Raja Marnangkok Naipospos yang merupakan cucu dari Raja Mulia Naipos-pos, yaitu salah satu tokoh penting yang mengembangkan Ugamo Malim, khususnya di Hutatinggi.

Desa Hutatinggi dikenal juga sebagai huta (Kampung) Parmalim atau tempat suci bagi Parmalim sebagai kepercayaan lokal di Hutatinggi. Parmalim sebagai salah satu kepercayaan lokal yang ada di Hutatinggi sudah sejak lama ada di tengah-tengah masyarakat Batak, karena Parmalim sendiri merupakan bagian dari kebudayaan Batak. Parmalim yang berkembang di Desa Hutatinggi didirikan oleh seorang tokoh spiritual, yaitu Raja Mulia Naipospos pada tahun 1921 yang merupakan murid dari Sisingamangaraja XII dalam masa perlawanan penjajahan Belanda saat itu. Parmalim telah menjadikan Sisingamangaraja XII sebagai tokoh sentral, 
karena 4 dianggap sebagai titisan Mulajadi Nabolon.

Pada awalnya parmalim adalah gerakan spritual untuk mempertahankan adat istiadat dan kepercayaan kuno yang terancam punah yang disebabkan oleh agama baru yang dibawa oleh para penjajah (Kolonialisme dan imperialisme). Parmalim umumnya tinggal di daerah Tapanuli yang hidup berdampingan dengan etnis Batak lainnya yang menganut agama Kristen seperti HKBP, GKPI, GKPA, GKPPD, GKPS dan lain sebagainya. Namun, pada belakangan ini agama Malim sudah menyebar sampai di beberapa wilayah, misalnya di Medan, Pekanbaru bahkan sampai di beberapa wilayah di Jawa.

Dalam kehidupan bersosial, kerapkali parmalim kurang mendapat perhatian baik dari pemerintah maupun dari masyarakat setempat. Penganut gereja arus utama sering menjustifikasi parmalim sebagai kelompok masyarakat yang menyembah roh nenek moyang atau sipelebegu. Oleh sebab itu penulis akan meneliti mengenai eksistensi atau keberadaan Agama Malim mempertahankan adat dan budaya Batak Toba di tengah-tengah kehidupan masyarakat di zaman modern masa kini.

\section{METODE PENELITIAN}

Penelitian ini

menggunakan

pendekatan deskriptif kualitatif yang bertujuan untuk menggambarkan secara ringkas berbagai kondisi dan fenomena sosial yang terjadi dalam realitas sosial masyarakat yang menjadi objek penelitian (Bungin, 2011). Dasar peneliti menggunakan metode penelitian kualitatif adalah agar penelitian ini mampu memberikan gambaran yang jelas, terinci, mendalam dan ilmiah yang menggambarkan kehidupan keagamaan dan sosial budaya serta pandangan masyarakat terhadap Parmalim. Untuk memperoleh data yang diperlukan dalam penelitian di lapangan, maka peneliti menggunakan teknik wawancara secara mendalam dengan melakukan proses tanya jawab dengan beberapa tokoh masyarakat baik dari kalangan penganut agama Malim maupun dari penganut agama di luar komunitas parmalim.

Selain pengumpulan data melalui teknik wawancara mendalam, peneliti juga melakukan observasi lapangan yang bertujuan mengidentifikasikan dan menginventarisasi berbagai fakta sosiologis yang ada di lapangan terkait eksistensi Parmalim di Desa Hutatinggi, Laguboti. Di samping penelitian melalui wawancara mendalam dan obeservasi lapangan, peneliti juga melakukan penelitian kepustakaan dengan menggunakan buku-buku atau literatur yang mendukung objek penelitian.

Hasil penelitian lapangan dan obervasi serta penelitian kepustakaan akan disajikan peneliti setelah melakukan analisa yang mendalam dan kritis. Oleh karena itu keakuratan data menjadi hal yang utama dan penting dalam penelitian ini. Penarikan kesimpulan di dasarkan atas hasil analisa terhadap hasil penelitian dan observasi serta studi kepustakaan yang dilakukan oleh peneliti. Dalam observasi ini, peneliti berusaha menguraikan eksistensi parmalim yang mengalami pertumbuhan dan perkembangan. Eksistensi yang diperlihatkan parmalim tentu tidak terlepas dari berbagai faktor, misalnya upaya yang dilakukan oleh para pengikut agama Malim untuk tetap mempertahankan eksistensi mereka di tengah-tengah masyarakat yang nonparmalim. Berbagai upaya yang dilakukan oleh parmalim dalam mengatasi berbagai hambatan yang muncul oleh arus modernisasi dan globalisasi. Lapangan penelitian atau observasi dilakukan di Hutatinggi, kecamatan, Laguboti Kabupaten Toba Samosir. Hutatinggi merupakan pusat daripada ugamo parmalim. Desa Hutatinggi merupakan salah satu desa yang terdapat di Kabupaten Toba Samosir, tepatnya di Kecamatan Laguboti, yang juga merupakan bagian dari Desa Pardomuan Nauli, tetapi masyarakat 
lebih mengenal desa ini sebagai Desa Hutatinggi.

\section{HASIL DAN PEMBAHASAN \\ Adat dan Budaya sebagai Way of Life dan Sentimen Kemasyarakatan}

Secara etimologi, kata eksistensi berasal dari bahasa latin yaitu exiztere yang artinya muncul, ada, timbul, memiliki keberadaan aktual. Istilah existere terdiri dari kata ex yang artinya keluar dan sistere yng artinya tampil atau muncul. Dari akar kata tersebut, istilah eksistensi dapat didefenisikan suatu kelompok masyarakat yang muncul ke permukaan dan tetap berada dalam komunitas masyarakat (Situmorang, 2017).

Dalam kaitannya dengan parmalim, bagaimana komunitas parmalim yang tampil di dalam masyarakat tetap berada dalam komunitas tersebut dengan menampilkan ciri khas yaitu adat dan kebudayaan Batak Toba tanpa tergerus oleh nilai-nilai yang dibawa oleh modernitas dan arus globalisasi. Eksistensi mencakup keberadaan dan perilaku dalam kehidupan sosial di lingkungan masyarakat. Menjadi tantangan tersendiri bagi parmalim, di tengah budaya popular yang digandrungi masyarakat, mereka tetap eksis mempertahankan adat dan budaya Batak toba sebagai nilai-nilai keyakinan dan berbagai ritus yang ada dalam keyakinan parmalim.

Menurut Roland Roberson dalam Furseth and Reptsad (2006), globalisasi merupakan proses yang telah membawa dunia untuk menjadi satu sistem sosialbudaya yang mendunia atau tatanan dunia yang telah dilembagakan. Modernisasi dipahami oleh para sosiolog sebagai proses unlinear yang berlangsung dalam batasbatas suatu negara atau bangsa. Ciri atau fenomena dari globalisasi adalah mempertanyakan dan mempersoalkan identitas-identitas masyarakat serta individu-individu. Globalisasi membawa peradaban yang berbeda ke dalam ruang publik yang satu.
Era modernitas meragukan dan mempertanyakan kebenaran. Dalam hal ini, agama dianggap ketinggalan zaman, tidak rasional. Intinya, modernitas mengembangkan pemikiran yang rasional ilmiah. Salah satu ciri modernitas adalah menekankan cara berpikir yang rasional. Modernisasi adalah proses perubahan masyarakat yang didominasi oleh cara berpikir rasional ilmiah Furseth and Reptsad (2006). Segala sesuatu yang tidak rasional akan ditinggalkan, sebaliknya sesuatu yang rasional akan digandrungi.

Modernitas yang membawa budaya popular dan rasional serta globalisasi yang mempertanyakan identitas masyarakat dan individu menjadi tantangan tersendiri bagi parmalim yang menekankan adat dan budaya sebagai keyakinan dan kepercayaan. Dalam perkembangannya, arus modernisasi dan globalisasi tidak mampu mereduksi nilai-nilai religius yang dihidupi oleh parmalim. Komunitas ini justru menjadi eksis bahkan semakin menyebar ke jantung kota (metropolitan), di mana budaya popular menjadi ciri khas.

Dari hasil penelitian dan observasi serta wawancara yang dilakukan oleh peneliti, parmalim telah menjadikan adat dan budaya Batak Toba sebagai way of life dan juga sebagai kepercayaan dan keyakinan. Dengan cara seperti inilah maka Agama Malim mampu bertahan (eksis) di tengah gempuran berbagai arus modernisasi dan globalisasi. Pada faktanya juga, bahwa parmalim tidak hanya mampu eksis justru mereka juga mampu merambah ke pusat kota metropolitan, misalnya Jakarta.

Sebagaimana yang diutarakan oleh Bapak D Sinambela dalam wawancara dengan peneliti, beliau mengatakan bahwa cara hidup pengikut agama Malim sangat dekat dengan alam. Selain itu, dalam ritualritual atau upacara-upacara yang dilakukan oleh parmalim sangat dominan dengan adat dan budaya Batak Toba. Dalam berpakaian selalu menggunakan ulos, dalam ibadah menggunakan gondang sekalipun industri 
musik sudah berkembang namun mereka tetap setiap memakai gondang dalam ibadah. Inilah salah satu yang dilakukan oleh parmalim untuk menjaga eksistensi budaya Batak Toba dengan tetap setia memakai ornamen, pakaian tradisional dan musik tradional dalam upacara keagamaan.

Dalam ajaran serta keyakinan parmalim, terlihat dengan jelas bagaimana ajaran parmalim mengakarkan adat dan budaya Batak Toba tersebut. Untuk mengakarkan ajaran Agama Malim, setiap pengikutnya diwajibkan untuk mengikuti ritus dan upacara. Seorang pengikut agama Malim atau parmalim, mulai dari lahir sampai mati ada beberapa upacara yang wajib diikutinya. Ada sembilan upacara yang wajib sebagai aturan dalam agama Malim, Martutuaek (Kelahiran), Pasahat Tondi (Kematian), Mararisabtu (Peribadatan setiap hari Sabtu), Mardebata (Peribadatan atas niat seseorang), Mangan Mapaet (Peribadahan memohon penghapusan dosa), Sipaha Sada (Peribadatan hari memperingati kelahiran Tuhan Simarimbulubosi), Sipaha Lima (Peribadatan hari persembahan/korban), Mamasumasu (Pemberkatan perkawinan), Marpangir (Menyucikan diri dengan memakai buah jeruk purut)

Ada tiga jenis ritus atau upacara dari dari sembilan upacara yang wajib diikuti pengikutnya yang harus menggunakan gondang (jenis musik tradisional Batak Toba) serta diiringi dengan tari-tarian (tortor). Adapun tiga upacara yaang harus diiringi gondang dan tari-tarian yaitu: Mardebata, Sipaha Sada dan Sipaha Lima. Ketiga ritus ini tidak boleh dipisahkan dari gondang dan tortor karena sudah merupakan bagian yang tidak terpisahkan. Adapun tujuan pemakaian gondang dan agar upacara peribadatan tersebut mendapatkan nilai yang paripurna (Wiflihani \& Suharyanto, 2011). Gondang merupkan salah satu identitas masyarakat Batak Toba yang masih terpelihara dalam komunitas parmalim. Musik gondang memiliki dimensi sosial dan spiritual (Harahap, 2012).

Salah satu upacara yang dilakukan oleh parmalim yang sarat dengan adat dan budaya Batak Toba adalah Marari Sabtu. Ritual Agama Malim secara rutin dilaksanakan setiap hari Sabtu, oleh karena itu sering disebut dengan "Marari Sabtu". Dalam ritus keagaamaan Marari Sabtu ini, semua umat memakai busana kebudayaan Batak Toba. Kaum bapak menggunakan ulos Batak kain putih yang diikatkan di kepala (sorban atau talitali) sedangkan kaum ibu mengenakan kebaya dan ulos serta sanggul (konde). Ulos tidak dapat dipisahkan dari setiap upacara dan kehidupan orang Batak karena memiliki dimensi spiritual (Situmorang, 2016). Pada saat upacara berlangsung, posisi duduk laki-laki dan perempuan terpisah dimana laki-laki mengambil tempat di sebelah kanan dan perempuan disebelah kiri (Suharyanto, 2012; 2014; 2016; 2019). Tujuan memisahkan laki-laki dan perempuan untuk menjaga kesucian mereka agar tidak berdosa serta mengarahkan umat untuk tetap fokus pada Tuhan yang disembah.

Pemakaian simbol dan berbagai ornamen adat dan budaya Batak Toba tidak hanya dalam upacara atau ritus, dalam bagunan peribadatan parmalim juga mengandung nuansa adat dan budaya Batak Toba. Pada atap bangunan peribadatan parmalim yang disebut dengan Bale Pasogit terdapat lambang tiga ekor ayam yang memiliki warna yang berbeda, yaitu hitam sebagai lambang kebenaran, putih lambang kesucian, dan merah sebagai lambang kekuatan dan kekuasaan. Ketiga warna ini merupakan warna dalam budaya Batak Toba yang juga diyakini sebagai tempat berdiamnya para dewata (Nainggolan, 2014). Dalam upacara keagamaan, semua laki-laki diwajibkan memakai sorban dan sarung, sementara bagi perempuan memakai sarung dengan rambut di sanggul. Dalam setiap ibadah doa 
upacara parmalim selalu diiringi dengan iringan musik tradisional.

Senada dengan Bapak D Sinambela, hal yang sama juga diutarakan oleh Bapak A Hutajulu. Menurutnya, komunitas Parmalim sangat menjaga kebersihan lingkungannya. Selain itu, pola hidup parmalim sangat menekankan kesederhanaan. Nilai-nilai hidup mereka bersumber dari nilai-nilai adat dan budaya Batak Toba. Mereka sangat setia menjalankan tradisi adat Batak Toba. Pengikut parmalim tidak terpengaruh dengan budaya populer. Hal ini dimungkinkan karena kepercayaan mereka itu terbentuk dari adat dan kebudayaan.

Kesetiaan dalam menjalankan ajaran menjadi salah satu kunci utama bagi parmalim dalam keberadaaan dan eksistensi mereka untuk mempertahankan adat dan budaya Batak Toba dalam setiap ritus yang dijalankan oleh komintas ini. Derasnya arus modernitas dan globalisasi yang membawa perubahan begitu cepat dalam segala lini tidak mampu mengubah tradisi dan kebiasaan yang dilakoni oleh para penganut agama Malim.

Budaya populer yang menjadi salah satu ciri dari modernitas dan globalisasi tidak mampu mereduksi nilai-nilai tradisional yang dihidupi oleh kelompok parmalim. Kesetian dan keteguhan para parmalim dalam menjalankan ritus, upacara dan juga nilai-nilai adat dan budaya menjadi senjata andalan untuk menangkal berbagai dampak yang dibawa oleh arus modernitas dan globalisasi. Sekalipun harus diakui bahwa dalam halhal lain, mereka juga dipengaruhi oleh modernisasi dan globalisasi.

Salah satu informan juga menguatkan pendapat yang sebelumnya, yaitu bapak Pendeta Pantas Mannullang, S.Th. Dalam penuturannya, beliau menguraikan bahwa parmalim sangat menghidupi ajaran-ajaran agamanya. Salah satu contoh ajaran dalam agama malim yaitu tentang larangan mencuri. Kasus-kasus pencurian tidak akan ada dalam komunitas parmalim, bahkan ketika barang (harta benda) jatuh atau ketinggalan di kompleks atau lingkungan parmalim, bisa dipastikan barang tersebut akan kembali. Parmalim sangat teguh menjungjung tinggi adat dan budaya Batak Toba, baik dalam ritual-ritual yang mereka jalankan, dalam perilaku hidup sehari-hari serta pada saat berinteraksi sosial dengan orang lain. Mereka tidak tergoda dengan budaya-budaya populer yang sedang berkembang pada masa kini.

Adat dan budaya telah menjadi cara hidup parmalim dalam berinteraksi dalam kehidupan sosial. bukan hanya itu saja, adat dan budaya juga telah menjadi sistim daripada nilai-nilai kepercayaan dan keyakinan Agama Malim sehingga sangat sulit untuk memisahkan adat dan agama karena sudah menyatu dengat kuat. Polapola beragama yang didominasi adat dan budaya dan juga telah menjadi bagian dari ritus menjadikan adat dan budaya menjadi sebuah patron yang kuat bagi kelompok parmalim. Menyatunya adat dan budaya atau dengan istilah lainsaling berkelindan dengan kepercayaan memiliki kekuatan yang sangat signifikan yang dapat membentengi para pengikutnya dari berbagai arus gelombang modernisasi dan globalisasi.

Untuk tetap eksis dalam ajaran agamanya, parmalim juga memelihara sentimen keagamaan. Teori sentimen keberagamaan pertama sekali dimunculkan oleh seorang ilmuwan dari Prancis yaitu Emile Durkheim. Menurut teori sentimen keberagamaan ini, untuk mempertahankan kepercayaan tetap eksis maka sentimen kemasyarakatan dipelihara. Menurut pandangan teori ini bahwa agama itu muncul pertama sekali karena adanya suatu getaran jiwa dan emosi yang ditimbulkan dalam jiwa manusia sebagai sesama warga masyarakat. Menurut Durkheim bahwa agama mampu menjaga eksistensinya juga disebabkan oleh faktor adanya sentimen kemasyarakatan (Durkheim, 1965). Agama tidak terlepas dari realitas sosial yang membentuknya, 
dalam hal ini parmalim memiliki realitas agama yang dibentuk keyakinan dan praktik-praktik keagamaan yang didominasi oleh adat dan budaya dalam ritus maupun upacara-upacara yang dilakukan. Ikatan dan perasaan setiap anggota dalam kelompok semakin diperkuat oleh relasi dan interaksi antar sesama.

\section{Aktif Terlibat dalam Interaksi Sosial dengan Masyarakat Sekitar}

Derasnya perkembangan zaman yang ditandai dengan perubahan yang begitu cepat dalam segala aras kehidupan (disrupsi). Arus perubahan ini menuntut agar setiap level sosial dan kehidupan untuk beradaptasi dengan peruahan zaman. Pesatnya perkembangan zaman tidak serta-merta menjadikan Agama Malim menjadi punah justru sebaliknya tetap eksis bahkan merambah ke berbagai daerah dan kota-kota besar. Faktor keterlibatan dalam interaksi sosial dengan sesama dan juga masayarakat sekitar menjadi penentu dalam eksistensi suatu agama atau komuitas. Peran sosial dalam masyarakat sangat berpengaruh dalam eksistensi suatu agama.

Dari hasil penelitian serta observasi dan wawancara yang dilakuka oleh peneliti, tampak dengan jelas kehidupan sosial parmalim yang ditandai dengan interaksi yang sangat intensif dengan masyarakat sekitar di Desa Hutatinggi, Laguboti. Tidak dapat dipungkiri bahwa interaksi ini didasarkan pada kesamaan adat dan budaya dengan masyarakat sekitar. Perbedaan agama dan keyakinan dengan masyarakat sekitar pada umumnya tidak menjadi penghalang dalam membangun relasi komunal dengan sesama penduduk Hutatinggi. Dalam penelitian penulis, memang ada juga yang masih memandang parmalim sebagai penganut Animisme (Sipelebegu).

Dari hasil penelitian penulis, para informan pada umumnya merasakan hubungan yang harmonis dengan parmalim. Hal itu ditandai dengan interkasi yang terbangun dengan masyarakat ketika ada kegitan-kegiatan sosial dalam lingkungan tersebut. Sebagaimana yang diutarakan oleh bapak D Sinambela melalui wawancara, beliau mangatakan bahwa parmalim cukup aktif dalam bersosialisasi dengan masyarakat sekitar. Parmalim juga memperlihatkan sikap yang ramah dan tetap menunjukkan sisi paradaton (ikut terlibat dalam acara adat). Hal ini menunjukkan bahwa mereka juga menghormati akan orang lain. Bapak Sinambela juga mengatakan bahwa Parmalim juga ikut terlibat dalam interaksi sosial dengan masyarakat sekitar. Hal ini bisa dilihat dalam bekerja bersama di pasar untuk berjualan dan dalam aktifitas bertani. Dalam hal ini, ruang-ruang interaksi sosial yang umum yakni di Pasar dan pertanian, parmalim meleburkan diri aktif dalam kegiatan sosial tersebut.

Penuturan yang sama juga diperlihatkan oleh bapak A. Hutajulu, dalam keterangannya beliau mengatakan bahwa kehidupan yang terjalin di tempat mereka yang bersebelahan dengan desa Parmalim merupakan kehidupan yang baik dan harmonis, tidak ada konflik yang disebabkan oleh agama. Para penganut Agama Malim umumnya ramah dan memilki hubungan yang baik dengan masyarakat. Pada saat ada hajatan atau pesta adat, mereka datang memenuhi undangan meskipun yang memiliki hajatan berbeda keyakinan atau agama dengan mereka. dalam hal ini terlihat bahwa kehidupan parmalim tidak tertutup namun membuka diri. Dalam artian, kehidupan parmalim tidaklah eksklusif atau fanatik dengan ajaran agamanya. Justru sebaliknya, parmalim terbuka dengan masyarakat sekitar. Hal ini diperlihatkan dengan kesediaan untuk menghadiri kegiatankegiatan sosial yang terjadi dalam masyarakat sekalipun memiliki keyakinan yang berbeda. Namun, karena parmalim tidak memakan daging Babi, mereka makan di tempat yang sudah disediakan oleh pihak 
yang memiliki hajatan dengan lauk tertente.

Menurut pengakuan Pdt. P Manullang, bahwa parmalim yang ada di daerah pelayanannya sangat ramah kepada masyarakat sekitar. Namun, menurut keterangan Pdt. P Manullang bahwa parmalim cenderung terlihat bahwa mereka menghindari gereja dan tidak terlalu suka membahas agama dengan masayarakat. Tentu keengganan parmalim membicarakan agama dan juga gereja patut "dimaklumi" sekalipun tidak bisa dibenarkan sikap yang demikian. Menurut penulis, hal ini terjadi karena pada umumnya gereja selalu memandang parmalim sebagai agama yang sesat dan penyembah berhala. Para pengikut Agama Malim sering dianggap manusia yang perlu menerima diinjili dan dibrikan pertobatan. Pemahaman yang demikian tentu dapat menjadi hambatan dalam membangun relasi komunitas dalam masyarakat. Pandangan yang melihat bahwa parmalim adalah agama yang sesat tidaklah adil karena cara pandang seperti ini sudah dipengaruhi oleh pemikiran orientalisme yang kental, dan juga pengaruh kolonialisme serta imperialisme yang dibawa oleh penjajah (Said, 2010).

Menurut Pdt. P Manullang, dalam adat atau pesta orang Batak, parmalim akan hadir memenuhi undangan dengan sukacita dan terlibat aktif dalam acara adat tersebut. Perilaku ini membuktikan bahwa parmalim bukan masyarakat yang tertutup. Mereka akan cenderung menghindari percakapan atau pembahasan ketika langsung terkait dengan agama atau kepercayaan. Keengganan mereka kepada gereja bukan karena faktor kebencian, melainkan untuk menghindari retaknya relasi sosial yang sudah terjalin dengan baik akibat percakapan-percakapan yang menyangkut keyakinan dan agama.

\section{Fungsi Agama membentuk Kohesi Sosial Parmalim}

Agama memiliki fungsi dalam kehidupan masyarakat. Menurut John Saliba (Saliba, 2003), ada lima fungsi agama dalam masyarakat sosial, yaitu: Fungsi eksplanatori; Fungsi emosional; Fungsi sosial; Fungsi validasi; Fungsi adaptif.

Teori fungsi agama ini berperan dalam komunitas parmalim sebagai kohesi sosial sehingga eksistensi mereka tetap terjaga di tengah berbagai gejolak dan perkembangan zaman. Agama bisa memiliki fungsi yang berbeda bagi setiap orang, sejauh agama itu memiliki fungsi maka agama itu memiliki kekuatan sosial untuk mengikat anggotanya. Di tengah arus modernisasi dan globalisasi, kekuatan individualistik yang semakin menonjol maka agama memiliki kekuatan untuk mempersatukan dan mengikat. Agama mampu membentuk soliditas dan solidaritas sosial dalam sebuah komunitas.

Fungsi Agama menurut John Saliba ada lima di mana setiap fungsi itu memiliki kekuatan dalam membentuk dan menguatkan ikatan dalam setiap anggotanya karena melibatkan berbagai unsur termasuk emosional. Ketika agama itu memberikan rasa aman bagi pengikutnya, maka kohesi sosial semakin kuat. Dalam hal ini, sepertinya Agama Malim mampu menjalankan fungsinya dengan baik sehingga tetap eksis dalam gempuran berbagai arus modernisasi dan globalisasi.

Dari hasil wawancara dengan ibu A Sitompul (salah satu pengikut Agama Malim) terlihat bahwa Agama itu memiliki Fungsi Sosial dalam komunitas mereka. Agama itu bersifat instrumental bagi parmalim dan sekaligus mengikat solidaritas di antara mereka. Dalam berperilaku dan tata cara hidup, agama Malim menginstrumental setiap pengikutnya untuk hidup sesuai dengan nilai-nilai agama Malim. Nilai-nilai dalam agama itu mengikat solidaritas di antara 
mereka sehingga tetap eksis sampai pada masa kini.

Agama menjadi perekat sosial bagi pengikut parmalim. Oleh karena itu, kohesi sosial ini selalu dijaga dengan baik oleh pemimpin dan setiap anggotanya. Adat dan budaya yang kemudian dijadikan sebagai agama dan kepercayaan, terbukti kuat dalam membentuk serta membentengi diri para pengikutnya dari berbagai arus modernisasi dan globalisasi yang melanda setiap sendi dan ikatan sosial manusia.

Adat dan budaya yang telah menjadi keyakinan dan kepercayaan Agama Malim mampu memainkan dimensi emosional para pengikutnya sehingga merasa aman dalam komunitas tersebut. Fakta yang sangat jelas, bahwa orang Batak itu sangat mencintai adat dan kebudayaannya. Bagi orang Batak, lebih malu dikatakan jika tidak memiliki adat dibandingkan dengan tidak memiliki agama. Faktor ini menjadi unsur yang sangat penting dalam menjaga eksistensi parmalim dalam perkembangan arus moderisasi dan globalisasi.

Eksistensi parmalim dalam arus modernisasi dan globalisasi tidak terjadi begitu saja. Sebagaimana yang telah diuraikan di atas, ada beragam faktor yang menjadikan parmalim teta eksis sampai pada masa kini. Teori dan hasil penelitian telah memperlihatkan sejauhmana parmalim berupaya mempertahankan ajaran dan keyakinanan mereka dalam era modern masa kini. Eksistensi parmalim terlihat dalam beberapa hal, yakni:

\section{Eksistensi Adat dan Budaya dalam Ritus Ibadah}

Dari hasil penelusuran dan penelitian, baik kepustakaan dan penelitan lapangan melalui wawancara mendalam, terlihat bagaimana parmalim eksis dalam mempertahankan ajaran agama dan nilainilai adat dan budaya Batak Toba. Jika ditelusuri dari bentuk ritus, materi-materi yanng digunakan dalam ritus, jenis musik yang dipakai dalam peribadatan serta pakaian yang digunakan pada saat ibadah atau mararisabtu, sangat jelas sekali semuanya memakai unsur-unsur adat dan budaya Batak Toba.

Dalam hal beribadah, Agama Malim membersihkan dirinya terlbeih dahulu dengan marpangir (jeruk purut) tanaman khas orang batak Toba, termasuk membakar kemenyan sebelum memulai ibadah. Dalam ibadah, setiap laki-laki menggunakan sorban dan mandar (sarung) dan wanita menggunakan ulos, sarung dan rambut disanggul. Pada masa modern sekarang ini, pakaian seperti itu kurang diminati bahkan cenderung ditinggalkan dalam ibadah-ibadah gereja kesukuan arus utama etnis Batak.

Pemimpin Agama Malim yaitu Bapak Monang Naipospos juga sangat menekankan anggotanya untuk hidup suci dan menghidupi nilai-nilai adat dan budaya Batak Toba. Misalnya, tentang nilai kebersihan, nilai-nilai moral, penghormatan terhadap orang lain, peduli kepada orang lain. Nilai-nilai itu termaktud dalam budaya Dalihan na Tolu. Dalam menjalankan relasi sosial dan juga ritus ibadah selalu menonjolkan adat dan budaya serta kearifan lokal. Pemimpin dan para pengikutnya tidak terkontaminasi dengan budaya popular yang sedang berkembang, sekalipun dalam hal-hal tertentu parmalim menyesuaikan diri dengan perkembangan zaman dan teknologi.

\section{Eksistensi dalam Simbol dan Alat Musik Tradisional}

Dalam peralatan musik, Agama Malim menggunakan gondang Sabangunan untuk mengiringi setiap ibadah yang mereka laksanakan. Mereka tidak terpengaruh dengan jenis-jenis musik modern seperti keyboard, saxopone, dan lain sebagainya. Di gereja-gereja kesukuan etnis Batak, lebih cenderung menggunakan alat-alat musik modern dan canggih bahkan musik box sudah masuk dalam gereja-gereja. Namun harus dipahami bahwa dalam hal ini parmalim tidak anti dengan jenis musik 
modern, mereka juga tidak anti dengan teknologi yang serba canggih. Dalam hal ini, parmalim juga tidak menolak perkembangan zaman, justru Agama Malim ini memberikan persepktif bahwa adat dan budaya masih memiliki ruang dan tempat dalam konteks zaman yang semakin modern nan canggih.

Dalam hal tata ibadah atau ritual, sangat kental dengan nuansa adat dan budaya Batak Toba. Simbol-simbol yang digunakan, ritus-ritus dan persembahan yang diberikan memperlihatkan suasana atau dekorasi yang sangat kental dengan etnis Batak Toba. Dalam gereja-gereja kesukuan etnis Batak, sangat minim sekali nuansa adat dan budaya Batak Toba bahkan hampir semuanya diimport dari luar. Pemakaian simbol yang sangat kental dengan adat dan budaya Batak dalam ritus atau upacara keagamaan dapat juga memperkuat relasi sosial di antara pengikut agama Malim.

Dalam beberapa jenis ritus yang ada adalam ajaran parmalim, harus diiringi gondang dan tortor. Dalam arti bahwa gondang dan tortor bagian integral dari upacara tersebut. Simbol tiga ekor ayam yang memiliki warna yang berbeda yaitu hitam, putih dan merah memperlihatkan wana khas orang Batak. Budaya orang Batak hanya mengenal ketiga warna tersebut, dan ini dibuat dalam simbol ayam yang memiliki ketiga warna tersebut.

\section{Eksistensi dalam Relasi dengan Masyarakat}

Dari hasil wawancara menunjukkan bahwa Agama Malim ataupun pengikutnya sangat menjungjung tinggi adat dan budaya Batak Toba yang tercermin dalam kearifan lokal. Mereka terlibat aktif dalam pesta adat yang dilaksanakan oleh orang lain meskipun berbeda keyakinan. Adat dan budaya menjadi cara hidup dan berperilaku mereka sehari-hari. Adat dan kebudayaan telah dijadikan sebagai agama dan kepercayaan bagi pengikut parmalim. Dengan demikian, cara hidup dan perilaku para pengikut parmalim tidak terlepas dari adat dan budaya Batak Toba.

Hubungan dengan masyarakat sekitar terjalin dengan baik, hai itu terbukti dengan keterlibatan dalam aktvitas sosial yang terjadai di dalam lingkungan sekitar. Namun, secara khusus dengan gereja HKBP ada kencenderungan menghindari. Hal ini disebabkan oleh pandangan negatif dari gereja-gereja yang bersifat kesuskuan secara khusus gereja HKBP yang mayoritas jemaatnya adalah Batak Toba sering menilai dan menganggap parmalim sebagai penyembah berhala dan aliran sesat.

\section{SIMPULAN}

Menurut penulis, Agama Malim mampu bertahan dari berbagai ancaman modernisasi maupun globalisasi karena nilai-nilai adat sudah tercermin dalam ritus peribadatan dan pemujaan mereka. Dengan demikian, parmalim tidak mudah terpengaruh oleh arus perubahan yang dibawa oleh modernitas dan globalisasi. Parmalim menjadi salah satu dari berbagai komunitas yang masih setia menghidupi adat dan budaya Batak Toba, baik dalam ritus keagaman maupun dalam berinteraksi dengan masyarakat dalam lingkungan sosial.

Agama Malim merupakan sebuah ajaran kepercayaan yang muncul dari budaya Batak Toba. Prinsip dari penganut Agama Malim adalah mempertahankan kebudayaan Batak Toba dengan baik. Hasil penelitian penulis menunjukkan bahwa parmalim memiliki susunan keagamaan yang teratur yang sangat berpengaruh terhadap para pengikutnya. Dalam Agama Malim sendiri memiliki kepercayaan terhadap Mulajadi Nabolon, dan mereka juga memiliki tata ibadah, kesaksian iman, dan hukum yang sangat kental dengan nilai-nilai adat dan budaya Batak Toba yang kemudian diwariskan secara lisan maupunn tulisan kepada setiap generasi berikutnya.

Salah satu kunci keberhasilan parmalim eksis mempertahankan dan 
menghidup nilai-nilai adat dan budaya karena sudah menyatu dengan kehidupan mereka lewat ritus dan pemujaan terhadap Debata Mulajadi na Bolon. Ajaran yang telah melekat dan dihidupi dalam perilaku membuat parmalim tidak mudah tergoda akan perubahan-perubahan yang ditawarkan oleh arus modernisasi dan globalisasi.

\section{Ucapan Terimakasih}

Berterimakasih kepada kedua orang tua, Istriku, dan anakku atas semua dukungan moril dan materi selama kuliah di Universitas Kristen Satya Wacana.

\section{DAFTAR PUSTAKA}

Bungin, B. 2011. Penelitian Kualitatif. Jakarta: Kencana Predana Media Group

Durkheim, E, (1965), The Elementary Forms of The Religious Life, New York, The Free Press.

Furseth, I., \& Reptsad, P., (2006). An Introduction to the Sosciology of Religion: Classical and Contemporary Perspectives, Aldershot, England Burlington: Ashgate Publising.

Harahap, I., (2012). Gondang Di komunitas Parmalim Batak Toba: Teks, Konteks, Dan Aspek Performatif. Universitas Indonesia, Antropologi Indonesia, 33 (1), 60-70.

Hirosue, M., (2015). The parmalim movement and its relations to $\mathrm{Si}$ Singamangaraja XII: A Rreexamination of the development of religious movements in Colonial Indonesia, USU, Etnovisi, 1 (3), 110-120

Katimin, (2012). Pertumbuhan dan perkembangan Parmalim di Sumatera tahun 1885-sekarang, UINSU, Journal Analityca Islamica, 1 (2), 190 200.
Moleong, L.J., (2011). Metodologi Penelitian Kualitatif. Edisi Revisi, Cetakan ke 29, Bandung: PT Remaja Rosdakarya Offset.

Said, E.W., (2010). Orientalisme: Menggugat hegemoni Barat dan mendudukkan timur sebagai subjek, Yogyakarta: Pustaka Pelajar.

Saliba, J., (2003). Understanding New Religious Movement, edition 2, Walnut Creek: Altamira Press.

Siagian, R.J., (2016). Sahala Bagi Pemimpin: Dulu dan Kini, Pematangsiantar: Lembaga Bina Warga HKBP.

Situmorang, N., (2017). Eksistensi Agama lokal Parmalim, Bina Widya, JOM FISIP, 4 (1), 1-10

Situmorang, I.M., dkk, (2016). Eksistensi Ulos pada Upacara Kematian Sari matua pada Masyarakat Batak Toba, UNIMED, Antrophos, 2 (1). 120-131

Situmorang, S., (2009). Toba Na Sae, Jakarta: Komunitas Bambu.

Suharyanto, A. (2012). Makna Gondang dan Tort-tor dalam Upacara Ritual Parmalim Nasiak Bagi di Hutatinggi Laguboti Toba Samosir dalam Apresiasi Simbol dalam Seni Nusantara 1, 5973, Bandung: CV. Bitang Warli Artika

Suharyanto, A. (2014). Tubuh Tari: Dimensi Sosial dan Transedental, Harian Analisa Medan,

Suharyanto, A., (2016), Pusat Aktivitas Ritual Kepercayaan Parmalim di Huta Tinggi Laguboti, JPPUMA: Jurnal Ilmu Pemerintahan dan Sosial Politik UMA (Journal of Governance and Political UMA), 4 (2): 182-195.

Suharyanto, A. (2019). Makna Ritual Marari Sabtu Pada Ruas Ugamo Malim, JISA (JURNAL ILMIAH SOSIOLOGI AGAMA) 2 (1), 14-28

Sutrisno, M., dan Putranto, H., (2005). Teori-Teori Kebudayaan, Yogyakarta: Kanisius.

Nainggolan, T., (2014). Sejarah \& Transformasi Religi, Medan: Bina Media Perintis.

Wiflihani \& Suharyanto, A., (2011). Upacara Sipaha Sada Pada Agama Parmalim Di Masyarakat Batak Toba dalam Kajian Semiotika, JUPIIS; Jurnal Pendidikan Ilmu-ilmu Sosial, 3 (1), 104115. 